Pesq. Vet. Bras. 35(6):497-500, junho 2015

DOI: $10.1590 / \mathrm{S} 0100-736 \mathrm{X} 2015000600002$

\title{
Oestrus ovis infection of grazing sheep during summer in southern Chile ${ }^{1}$
}

\begin{abstract}
Alejandro Hidalgo ${ }^{2,3,4 *}$, Héctor Palma ${ }^{4}$, Carlos Oberg ${ }^{5}$ and Flery Fonseca-Salamanca ${ }^{2,3}$
ABSTRACT.- Hidalgo A., Palma H., Oberg C. \& Fonseca-Salamanca F. 2015. Oestrus ovis infection of grazing sheep during summer in southern Chile. Pesquisa Veterinária Brasileira 35(6):497-500. Laboratorio de Inmunoparasitología Molecular, BIOREN-CEGIN, Unidad de Parasitología, Departamento de Ciencias Preclínicas, Universidad de La Frontera, Casilla 54 D, Avda. Alemania 0458, Temuco, Chile. E-mail: jose.hidalgo@ufrontera.cl

Oestrus ovis is a botfly whose larvae cause nasal myiasis, an environmental-dependent disease in small ruminants, generating acute and chronic injuries in the cranial cavities of sheep. Chile is a country of the southernmost worldwide distribution of this parasite, and there is few information about. Whence, the objective of this study was to approximate the epidemiological situation of O. ovis infection in Chilean sheep. From December 2009 to March 2010, a total of 87 samples were obtained by necropsy for skull inspection. The larvae were collected, and microscopically identified. The prevalence in the sampled sheep was $60.9 \%$. From those that were infected, $85.7 \%$ (18/21) of sheep were 1 to 3 years old, constituting the stratum with the highest prevalence. The difference of infection in females and males was not significant. The high risk of infection seems to be dependent upon the environmental conditions of this southern region, especially during summer when the first larval stage (L1) could be found as the evidence. Therefore, the disease should be considered as a significant problem for this kind of livestock production.
\end{abstract}

INDEX TERMS: Oestrus ovis, sheep, larval stages, myiasis, botfly.

\section{INTRODUCTION}

Oestrus ovis is a parasite botfly that belongs to the Oestridae family of the Diptera order whose larval stages cause cavitary myiasis in the paranasal sinus of sheep, goats and other animals, including humans accidentally. (Acha \& Szyfres 2003).

The adult flies gather in groups, copulate in the environment, and after two weeks the females lay their first larval stage (L1). These hatch in the oronasal region of sheep and then crawl into the mucosa of the nasal cavities (Wall \& Shearer 1997). After a variable period of time, L1 cra-

\footnotetext{
${ }^{1}$ Received on December 2, 2014.

Accepted for publication on May 21, 2015.

${ }^{2}$ Laboratorio de Imunoparasitología Molecular, BIOREN-CEGIN, Unidad de Parasitología, Departamento de Ciencias Preclínicas, Facultad de Medicina, Universidad de La Frontera, Casilla 54 D, Temuco, Chile. *Corresponding author: jose.hidalgo@ufrontera.cl

${ }^{3}$ Programa de Doctorado en Ciencias, Biología Celular y Molecular Aplicada, Universidad de La Frontera, Temuco, Chile.

${ }^{4}$ Escuela de Medicina Veterinaria, Universidad Santo Tomás, Temuco, Chile.

${ }^{5}$ Facultad de Ciencias de la Salud, Universidad Católica de Temuco, Chile.
}

wls toward the nasal turbinates where it transforms to the second stage (L2), which then migrates to the sinuses and becomes the third stage known as L3 (Jacquiet \& Dorchies 2002).

Once they reach full development, L3 are expelled through sneezing and enter the soil for change to pupae. The transformation from L1 to L3 takes approximately 25 days in warm temperatures, but the prepatent period is often longer in cold weather conditions (Soulsby 1987).

Temperatures below $10^{\circ} \mathrm{C}$ reduce the occurrence of the infection since adult flies are susceptible to low temperatures. Under these conditions, the larval stages may enter a hypobiotic state, arresting its development in the host. This mechanism is essential for the survival of the parasite until the arrival of the favorable period for the development of adults (Rossanigo et al. 2004, Ramos et al. 2006, Hanan 2013).

The larval stages cause irritation, thickening and bleeding of the mucous membranes in the host due to the action of the oral hooks and integumentary thorns (Shivasharanappa et al. 2011). This is expressed as rhinitis with an overproduction of mucus, which promotes the feeding of 
the larvae. Some animals may present a serious infection when the larvae enter the brain through the foramina and they may develop encephalitis, manifesting ataxia, hemiparesis and blindness (Mozaffari et al. 2013). Severe injury of the brain tissue may produce a characteristic behavior in sheep known as "gid" which resembles the lesion produced by Coenurus cerebralis, the larval stage of Taenia multiceps (Anwar et al. 2013).

Considering the cold winter season in southern Chile, the presence of new infections can only be observed from late spring to early autumn, coinciding with the reproductive activity of adult flies.

Currently, intensified production systems create ideal conditions for the high development of this type of parasitism in small ruminants. There is a consensus that the pathogenic effects of this infection cause a long-term decline of the immune response and body condition of sheep (Godara et al. 2009). Adding to these problems is the difficult control of this parasitism in the environment and the great disparity of its treatments (Arslan et al. 2009).

In Chile, during the last decade, small ruminant livestock has experienced a large increase, which makes it necessary to know the current situation of the diseases that affect sheep production. Some overviews have confirmed the presence of the $O$. ovis in the region, but they do not show the epidemiological aspects of this parasitism (Tagle 1966, Oberg et al. 1974, Alcaíno \& Gorman 1999). Therefore, the objective of this study was to approximate the epidemiological situation of the $O$. ovis infection in Chilean sheep which has been scarcely documented.

\section{MATERIALS AND METHODS}

Study location. From December 2009 to March 2010, 87 sheep between the ages of 5 months and 6 years were randomly selected as samples and slaughtered at a local slaughterhouse belonging to Nueva Imperial, La Araucanía region in southern Chile (384'00"S 725'00"0).

Analysis of samples. Necropsy of the animal heads was performed following the technique suggested for sheep (Robles \& Uzal 1991), which basically consisted of a sagittal cutting of the skull and a wash with a saline solution $(0.9 \%)$, allowed for inspection of the skull cavities and the recovery of smaller larvae.

The collected larvae were fixed in Kahle's solution and microscopically observed (4X magnification) to evaluate the morphometric structures of interest. The identification of larval stages was performed using the morphological criteria described by Martínez et al. (1999).

Sheep samples were grouped according to age: $<1$ year, 1-3 years, and $>3$ years of age; and sex: male and female.

Environmental condition as weather temperatures (means), total rainfall $(\mathrm{mm})$ and relative humidity were compiled from the local meteorological station.

Statistical analysis. Analysis was descriptive and the results were expressed by prevalence of infection, defined as the number of affected individuals in the sampled population $(n=87)$, and they were divided into groups according to sex and age, and the period (season) and sub-periods (months).

The distribution of larval stages was expressed in number and percentage according to its type, with L1, L2, L3, and CL as calcified larvae, based on total larvae collected during each month. The calculation for intensity of infection was based on the number of collected larvae divided by the number of infected ones in each month and over the total sampling period.

Non parametric Kruskal-Wallis test was used to detect significant differences in prevalence by sex and age $(\mathrm{p}<0.05)$.

\section{RESULTS}

The overall prevalence of parasitized sheep by Oestrus ovis larvae was $60.9 \%$ (53/87). The highest prevalence was observed in December, with $67.9 \%$ of sheep infected (19/28), coinciding with the highest number of slaughtered animals. The lowest prevalence was recorded in February (47.1\%, 8/17).

The total of collected larvae was 281 specimens, with December yielding the greatest collection $136(48.4 \%)$ and March yielding the smallest 18 (6.4\%).

The mean of $4.8 \pm 0.7$ larvae (calculated according to the total of infected sheep, $n=53$ ) represents the estimated intensity of infection among the infected group. The smallest number of larvae per animal was 1 and the greatest was 19.

The observations showed that L2 (44.8\%) and L3 (39.9\%) were larval stages with higher number of collected specimens. These instars also presented similar values during each month (Table 1). The lowest findings were the calcified larvae, which yielded a prevalence of $4.3 \%$ $(12 / 281)$.

In regards to the occurrence of infection by sex, the prevalence in females $(65.9 \%, 30 / 47)$ than in males $(55.0 \%$, $23 / 40$ ) was not significant statistically.

With respect to prevalence by age, the most frequently affected group was that of 1-3 years, with $85.7 \%(18 / 21)$, (Table 2).

The mean environmental temperature during this study was similar in each month at $14.3^{\circ} \mathrm{C}$. The mean relative humidity was $75.1 \%$, reaching the highest value in Mar-

Table 1. Larval stages identified, number and percentage of each stage: first stage (L1), second stage (L2), third stage (L3) and calcified larvae (CL)

\begin{tabular}{lccccc}
\hline Month & Larvae (\%) & \multicolumn{4}{c}{ Larval stages (\%) } \\
\cline { 3 - 6 } & & L1 & L2 & L3 & CL \\
\hline December & $136(48.4)$ & 0 & $67(49.3)$ & $65(47.8)$ & $4(2.9)$ \\
January & $101(35.9)$ & $24(23.8)$ & $42(41.6)$ & $32(31.7)$ & $3(3.0)$ \\
February & $26(9.3)$ & 0 & $13(50.0)$ & $8(30.8)$ & $5(19.2)$ \\
March & $18(6.4)$ & $7(38.9)$ & $4(22.2)$ & $7(38.9)$ & 0 \\
Total & $281(100)$ & $31(11.0)$ & $126(44.8)$ & $112(39.9)$ & $12(4.3)$
\end{tabular}

Table 2. Prevalence of Oestrus ovis infection in sheep heads distributed by age

\begin{tabular}{lccccccc}
\hline Month & $\begin{array}{c}\text { Heads } \\
(\%)\end{array}$ & $\begin{array}{c}<1 \\
(\%)\end{array}$ & $\begin{array}{c}\text { Infected } \\
<1(\%)\end{array}$ & $\begin{array}{c}1-3 \\
(\%)\end{array}$ & $\begin{array}{c}\text { Infected } \\
1-3(\%)\end{array}$ & $\begin{array}{c}>3 \\
(\%)\end{array}$ & $\begin{array}{c}\text { Infected } \\
>3(\%)\end{array}$ \\
\hline December & 28 & 1 & 0 & 7 & 6 & 20 & 13 \\
& $(32.2)$ & $(3.6)$ & & $(25.0)$ & $(85.7)$ & $(71.4)$ & $(65.0)$ \\
January & 23 & 4 & 2 & 12 & 10 & 7 & 2 \\
& $(26.4)$ & $(17.4)$ & $(50.0)$ & $(52.2)$ & $(83.3)$ & $(30.4)$ & $(28.6)$ \\
February & 17 & 10 & 3 & 2 & 2 & 5 & 1 \\
& $(19.5)$ & $(58.8)$ & $(30.0)$ & $(11.8)$ & $(100)$ & $(29.4)$ & $(20.0)$ \\
March & 19 & 19 & 12 & 0 & 0 & 0 & 0 \\
& $(21.8)$ & $(100)$ & $(63.2)$ & & & & \\
Total & 87 & 34 & 17 & 21 & 18 & 32 & 16 \\
& $(100)$ & $(39.1)$ & $(50.0)$ & $(24.1)$ & $(85.7)$ & $(36.8)$ & $(50.0)$
\end{tabular}


Table 3. Mean values of climatic conditions during the summer season (December 2009 to March 2010) in La Araucanía region from Chile

\begin{tabular}{lccccc}
\hline Month & \multirow{2}{*}{$\begin{array}{c}\text { Total rainfall } \\
(\mathrm{mm})\end{array}$} & $\begin{array}{c}\text { Relative } \\
\text { humidity (\%) }\end{array}$ & \multicolumn{3}{c}{ Mean of temperature ${ }^{\circ} \mathrm{C}$} \\
\hline December & 61.8 & 74.3 & 13.5 & 8.0 & 20.3 \\
January & 35.4 & 72.6 & 14.7 & 7.9 & 22.7 \\
February & 70.0 & 73.0 & 14.5 & 8.3 & 22.7 \\
March & 50.0 & 80.3 & 14.3 & 9.1 & 21.9 \\
Mean (period) & 54.3 & 75.1 & 14.3 & - & -
\end{tabular}

ch $(80.3 \%)$ and the lowest in January (72.6\%). The mean monthly rainfall across the four months was $54.3 \mathrm{~mm}$. The highest value of accumulated rainfall was observed in February $(70 \mathrm{~mm})$ and the lowest in January with $35.4 \mathrm{~mm}$ (Table 3).

\section{DISCUSSION}

The prevalence of parasitized sheep was similar to those observed in the studies of geographic regions with different climates in that the infected group exceeds half the population. In Saudi Arabia, Hanan (2013) found 53.5\% which is lower compared to data from Spain, which described a range of prevalence between $71.1 \%$ and $82.4 \%$ (Alcaide et al. 2003, Gracia et al. 2010). Research done in Morocco and Greece found similar prevalence rates (69.2\% and 75.9\%), although the weather in these countries are different (Pandey \& Ouhelli 1984, Papadopolus et al. 2010). However, the investigations performed by Silva et al. (2013) in Brazil yielded an even lower prevalence $(13.7 \%)$ despite the favorable climatic conditions where one would expect a higher prevalence.

In evaluating the intensity of infection, the results coincide with those of Silva (2013), who found a mean of 4.5 larvae per head. Both the prevalence and intensity of infection could be related to optimal climatic condition during the season, in addition to the probable failure or lack of treatment against the parasite (Dorchies et al. 1997).

The larvae collection was similar to those recorded by Arslan et al. (2009) and Silva (2013), who both indicate that the numbers of L1 were much less than L2 and L3. Furthermore, they each conclude that most of the L3 larvae in the early summer, probably as a survival strategy, given that the larvae did not complete their cycle due to unfavorable weather conditions (Tabouret et al. 2001). The presence of L1 represents new infections, which were found in January, coinciding with moderate mean temperatures and low rainfall, suitable conditions for the emergence and mating of adult flies (Rojas 2003).

Finding calcified larvae suggests that the prolonged hypobiosis of $\mathrm{L} 3$ would be a typical phenomenon in environments that present unfavorable conditions like cold weather. Many of these larvae die due to the over-extension of their presence in the tissues, and the result is calcification (Martínez et al. 1999).

The presentation of infection in females and males coincides with several authors, indicating that females and males are similarly affected. It seems that this trend could be due to factors, such as the selection and management of sheep production systems, rather than dependent factors like sex or physiological condition (Uslu \& Dik 2006, Jafari et al. 2009, Zewdu 2010).

The higher prevalence according to age shows that animals between 1 and 3 years old were more often affected, and the results agree with similar studies that report a number of approximately $75.5 \%$ infected (Yilma \& Genet 2000, Zewdu 2010). Although Arslan et al. (2009) found that animals older than three years showed a higher prevalence $(52.4 \%)$, this is consistent with the direct relationship between age and risk of infection over time. In sheep under 1 year, the percentage of infection was lower, coinciding with the distributions observed for Arslan et al. (2009) and Silva et al. (2013). It could be considered that in southern Chile the infection of lambs is late because the optimal environmental conditions for the larval lay process of female flies begins around spring probably. This could explain the higher abundance of late larval stages (L2 and L3) as a response to the low temperatures prevalent during the rest of the year. Ramos et al. (2006) reported no findings under $9.8^{\circ} \mathrm{C}$, suggesting that the most influential factor was the temperature. Likewise, other authors agree that the optimum temperatures occur in summer and spring (Silva et al. 2012). According to local meteorological records, the registered environmental conditions were optimal for the development of new infections by 0 . ovis in southern Chile.

Diagnostic by necropsy presents some limitations due to the reality of this region, the reasons being: a small number of ruminant slaughterhouses, limited donations of research material, and the concentration of sheep slaughtered during the summer months.

\section{CONCLUSIONS}

Oestrus ovis infection is present in Chile with a high prevalence, presenting several larval stages throughout the summer season.

The infection affected both sexes equally, but affected a higher percentage of middle-aged sheep.

The environmental conditions of summer in the region are sufficient to allow the infection of sheep. Therefore, it should be considered a significant problem in local livestock production.

Aknowledgements.- The authors are grateful for the support granted by Veterinary School of Universidad Santo Tomás and Universidad de La Frontera for financing this article through DIUFRO Project № DI 11_0036.

\section{REFERENCES}

Acha P. \& Szyfres B. 2003. Zoonosis y Enfermedades Transmisibles comunes al Hombre y los Animales. 3aㅡ ed. Organización Panamericana de la Salud, p.355-356.

Alcaíno H. \& Gorman T. 1999. Parásitos de los animales domésticos en Chile. Parasitol. Día. 23:33-41.

Alcaide M., Reina D., Sánchez J., Frontera E. \& Navarrete I. 2003. Seasonal variations in the larval burden distribution of Oestrus ovis in sheep in the southwest of Spain. Vet. Parasitol. 118:235-241.

Anwar S., Mahdy E., El-Nesr K., El-Dakhly K., Shalaby A. \& Yanai T. 2013. Monitoring of parasitic cysts in the brains of a flock of sheep in Egypt. Revta Bras. Parasitol. Vet. 22(3):323-330. 
Arslan M., Kara M. \& Gicik Y. 2009. Epidemiology of Oestrus ovis infestations in sheep in Kars province of north-eastern Turkey. Trop. Anim Health Prod. 41:299-305.

Dorchies P., Alzieu J. \& Cadiergues M. 1997. Comparative curative and preventive efficacies of ivermectin and closantel on Oestrus ovis (Linné 1758) in naturally infected sheep. Vet. Parasitol. 72(2):179-184.

Godara R., Sharma R. \& Sharma C. 2009. Aberrant infestation of goat mandibles with Oestrus ovis larvae. Trop. Anim. Health Prod. 42:137-139.

Gracia M., Lucientes J., Peribáñez M., Castillo J., Calvete C. \& Ferrer L. 2010. Epidemiology of Oestrus ovis infection of sheep in northeast Spain (Mid-Ebro Valley). Trop. Anim. Health Prod. 42:811-813.

Hanan B. 2013. Seasonal prevalence of Oestrus ovis L. (Diptera: Oestridae) larvae in infested sheep in Jazan region, Saudi Arabia. J. Parasitol. Vector Biol. 5(5):66-71.

Jacquiet P. \& Dorchies P. 2002. Towards a lower prevalence of Oestrus ovis infections in sheep in a temperature climate (South West France). Vet. Res. 33:449-453.

Jafari S., Negahban S., Tamadon A. \& Amin M. 2009. Prevalence and intensity of Oestrus ovis in sheep of Shiraz, southern Iran. Trop. Anim. Health Prod. 41:1259-1262.

Martínez S., Moreno T. \& Becerra C. 1999. Estrosis, p.396-397. In: Cordero del Campillo M. \& Rojo F. (Eds), Parasitología Veterinaria. McGraw-Hill-Interamericana, Madrid, España.

Mozaffari A., Shojaeepour S. \& Cheshmeh S. 2013. High mortality rate due to false gid in a sheep herd. J. Vet. Sci. Doi 10.1155/2013/ 650358

Oberg C., Díaz L. \& Valenzuela G. 1974. Parásitos identificados en bovinos, ovinos, suinos y equinos en el Laboratorio de Enfermedades Parasitarias de Escuela de Medicina Veterinaria, Universidad Austral de Chile. Boln Chil. Parasitol. 29:99-102.

Pandey A. \& Ouhelli H. 1984. Epidemiology of Oestrus ovis infection of sheep in Morocco. Trop. Anim. Health Prod. 16:246-252.

Papadopoulos E., Chaligiannis I. \& Morgan E. 2010. Epidemiology of Oestrus ovis L. (Diptera: Oestridae) larvae in sheep and goats in Greece. Small Rumin. Res. 89:51-56.

Ramos C., Bellato V., Pereira de Souza A., Silveira de Avila V., Caldeira G. \&
Augustinho G. 2006. Epidemiologia de Oestrus ovis (Diptera: Oestridae) em ovinos no Planalto Catarinense. Ciência Rural 36:173-178.

Robles C. \& Uzal F. 1991. Guía Práctica de Necropsia en Ovinos y Caprinos. Editorial Hemisferio Sur, Buenos Aires, Argentina, p.6-10.

Rojas M. 2003. Control y prevención de Oestrus ovis en Perú: caprinos de la Costa Norte. Revta Peruana Parasitol. 16:51-54.

Rossanigo C., Galli C. \& Benítez A. 2004. Eficácia de tres antiparasitarios contra Oestrus ovis en cabras infestadas naturalmente. Revta Med. Vet., Buenos Aires, 85:231-234.

Shivasharanappa N., Manjunatha R., Nitika S. \& Gupta V. 2011. Parasitic encephalitis caused by larvae of Oestrus ovis in Sirohi goat. Indian J. Vet. Pathol. 35(2):204-205.

Silva B., Basseto C. \& Amarante A. 2012. Epidemiology of Oestrus ovis (Diptera: Oestridae) in sheep in Botucatu, State of São Paulo. Revta Bras. Parasitol. Vet. 21(4):386-390.

Silva B., Puglia G., Braga T. \& Amarante A. 2013. Prevalence of Oestrus ovis (Diptera: Oestridae) in sheep from the São Paulo Central region, Brazil. Revta Bras. Parasitol. Vet. 22(1):18-21.

Soulsby E. 1987. Parasitología y Enfermedades Parasitarias en los Animales Domésticos. 7a ed. Nueva Editorial Interamericana, México D.F., México, p.430-431.

Tabouret G., Jacquiet P., Scholl P. \& Dorchies P. 2001. Oestrus ovis in sheep: relative third-instar populations, risk of infection and parasitic control. Vet. Res. 32:525-531.

Tagle I. 1966. Parásitos de los animales domésticos en Chile. Boln Chil. Parasitol. 21:118-121.

Uslu U. \& Dik B. 2006. Prevalence and intensity of Oestrus ovis in Akkaraman sheep in the Konya region of Turkey. Med. Vet. Entomol. 20:347-349.

Wall R. \& Shearer D. 1997. Myasis: Oestridae, p.210-213. In: Wall R. \& Shearer D. (Eds), Veterinary Entomology. Chapman and Hall, Springer, London, UK.

Yilma J. \& Genet A. 2000. Epidemiology of the sheep nasal bot, Oestrus ovis L. (Diptera: Oestridae), in Central Ethiopia. Rev. Méd. Vét. 151:143-150.

Zewdu E. 2010. Prevalence of ovine and caprine oestrosis in Ambo, Ethiopia. Trop. Anim. Health Prod. 2:1259-1262. 